Abstracta Iranica Abstracta Iranica

Revue bibliographique pour le domaine irano-aryen

Volume 25 | 2004

Comptes rendus des publications de 2002

Iran and the Surrounding World. Interactions in Culture and Cultural Politics. Seattle and London, University of Washington Press, 2002, 393 p., biblio., index.

Jean Calmard

(2) OpenEdition

Journals

Édition électronique

URL : http://journals.openedition.org/abstractairanica/4014

ISSN : 1961-960X

Éditeur :

CNRS (UMR 7528 Mondes iraniens et indiens), Éditions de l'IFRI

Édition imprimée

Date de publication : 15 mai 2004

ISSN : 0240-8910

Référence électronique

Jean Calmard, "Iran and the Surrounding World. Interactions in Culture and Cultural Politics. Seattle and London, University of Washington Press, 2002, 393 p., biblio., index. », Abstracta Iranica [En ligne],

Volume 25 | 2004, document 6, mis en ligne le 15 mars 2006, consulté le 25 septembre 2020. URL

http://journals.openedition.org/abstractairanica/4014

Ce document a été généré automatiquement le 25 septembre 2020.

Tous droits réservés 


\title{
Iran and the Surrounding World. Interactions in Culture and Cultural Politics. Seattle and London, University of Washington Press, 2002, 393 p., biblio., index.
}

\author{
Jean Calmard
}

1 Cet ouvrage regroupe quinze articles écrits par des spécialistes d'aspects très divers de la culture iranienne (histoire, politique, littérature, diplomatie, religion, éducation, sociologie, cinéma etc.). La chronologie s'étend de la période safavide (1501-1722) à nos jours, avec une priorité accordée au monde contemporain. En effet, près de la moitié du livre concerne la période commençant avec la révolution islamique de 1979. La matière, répartie entre études thématiques et celles s'inscrivant dans une chronologie précise, est divisée en cinq parties. La diversité des thèmes traités apparaît clairement dans la liste des intitulés fournie ci-après :

Introduction par Nikki R. Keddie, pp.3-12. Part I. Overviews : 1) Juan R. I. Cole, "Iranian Culture and South Asia, 1500-1900», pp. 15-35 ; 2) Ahmad Karimi-Hakkak, «Beyond Translation: Interactions between English and Persian Poetry », pp. 36-60 ; 3) Thomas J. Barfield, «Turk, Persian, and Arab: Changing Relationships between Tribes and State in Iran and along its Frontiers", pp. 61-88. Part II. The Safavids, Qajar, and Pahlavi Periods: 4) Abolala Soudavar, "The Early Safavids and Their Cultural Interactions with Surrounding States", pp.89-120; 5) Rudi Matthee, "Suspition, Fear, and Admiration: Pre-Nineteenth Century Iranian Views of the English and the Russians », pp. 121-145 ; 6) Monica M. Ringer, " The Quest for the Secret of Strength in Iranian Nineteenth-Century Travel Literature : Rethinking Tradition in the Safarnameh », pp. 146-161; 7) Firoozeh Kashani-Sabet, "Cultures of Iranianness : The Evolving Polemic of Iranian nationalism », pp. 162-181 ; 8) Jasamin Rostam-Kolayi, «Foreign Education, the Women's Press, and the Discourse of Scientific Domesticity in 
Early-Twentieth-Century Iran », pp. 182-204. Part III. Culture in the Islamic Republic in Relation to the World: 9) Nayereh Tohidi, "International Connections of the Iranian Women's Movement », pp. 205-231; 10) Golnar Mehran, « The Presentation of the "Self" and the "Other" in Postrevolutionary Iranian School Textbooks", pp. 232-253 ; 11) Hamid Naficy, "Cinematic Exchange relations : Iran and the West ", pp. 254-280. Part IV. Political-Cultural Relations with the Muslim World: 12) Wilfried Buchta, «The Failed Pan-Islamic Program of the Islamic Republic : Views of the Liberal Reformers of the Religious "Semi-Opposition" ", pp. 281-304 ; 13) Asef Bayat et Bahman Baktiari, "Revolutionary Iran and Egypt: Exporting Inspirations and Anxieties ", pp. 305-326; 14) Vali Nasr, "The Iranian Revolution and Changes in Islamism in Pakistan, India, and Afghanistan ", pp.327-354. Part V. The Politics of Iran's International Relations : 15) Gary Sick, « Iran's Foreign Policy : A Revolution in Transition », pp. 355-374.

3 Ces travaux examinent, dans une perspective historique, la place de l'Iran et de la culture iranienne dans le monde. En ce qui concerne les relations et les " interactions ", les voisins immédiats, dont la Russie et l'Inde britannique, ainsi que les États-Unis, apparaissent davantage que l'Allemagne ou la France (sauf dans le domaine de l'éducation). L'analyse s'étend cependant de l'Égypte à l'Inde. Dans certaines contributions, le contexte historique est, tout au plus, schématisé. Compte rendu détaillé à paraître dans Studia Iranica.

INDEX

Thèmes : 1.2. Recueils d'articles : revues, colloques, ouvrages collectifs

\section{AUTEURS}

JEAN CALMARD

CNRS - Paris 